\title{
LOURNAL.RU
}

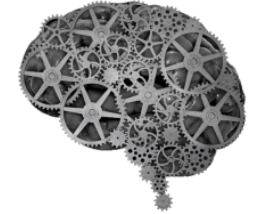

COMPANY GROUP "INTELLEKT"

Локшина Л.С., Горлинская Е.Н.

Горбольница № 1 им. Н.А. Семашко ЦРБ Морозовского района Ростовской области Ростов-на-Дону, Россия

doi: 10.18411/1j2016-3-24

\section{Хирургические вмешательства на небных миндалинах у детей}

Операции на лимфокольце глотки - самые распространенные хирургические вмешательства в детской оториноларингологической практике $[1$, 2]. Вместе с тем, взгляды на показания к тонзиллэктомии (ТЭ) на протяжение последних 30 лет претерпевали существенное изменение во всем мире, независимо от особенностей национальных стандартов и рекомендаций. Так, если в восьмидесятые годы основными показаниями к ТЭ в США были рецидивирующие тонзиллиты [3], то в настоящее время на первое место вышли вмешательства по поводу синдрома ночного апноэ [4]. Общее число ТЭ, выполненных в США уменьшилось с 1,4 млн в 1956 г до 418000 в 1996 г, то есть в 3.3. раза [5]. Такое перераспределение большинство авторов объясняют успехами антибактериальной терапии воспалительных заболеваний миндалин.

Вместе с тем, проблема борьбы с сопряженными с хроническим тонзиллитом заболеваниями не решена. По данным ВОЗ, острая ревматическая лихорадка (ОРЛ) и хроническая ревматическая болезнь сердца (ХРБС) попрежнему остаются наиболее распространенными сердечно-сосудистыми заболеваниями у детей, подростков и взрослых молодого возраста, поражая ежегодно как минимум 12 млн человек и являясь причиной 332 тысяч летальных исходов. Отсюда следует, что борьба с ростом ревматических заболеваний 
должна включать лечение хронического тонзиллита, направленное на профилактику ангины и рациональную терапию острого стрептококкового тонзиллофарингита.

В оториноларингологической практике самым ярким проявлением декомпенсации хронического тонзиллита является паратонзиллит / паратонзиллярный абсцесс.

Целью нашего исследования было изучение динамики двух взаимосвязанных показателей: количества планово выполненных тонзилэктомий у детей и числа больных, госпитализированных по поводу паратонзиллярного абсцесса.

Материал и методы исследования. Анализ изучаемых статистических показателей проведен по архивным материалам детского ЛОР отделения горбольницы № 1 г. Ростова-на-Дону. Это отделение является единственным в миллионном городе стационаром по оказанию круглосуточной экстренной помощи больным с заболеваниями ЛОР органов, а также основным центром плановой госпитализации ЛОР больных. Мы произвели выборку архивных историй болезни детей, госпитализированных паратонзиллит/паратонзиллярный абсцесс и больных, госпитализированных на плановое хирургическое лечение по поводу хронического тонзиллита за 2 трехлетних периода, разделенных между собой 15-летним интервалом (1994 1996 и 2009 - 2011 годы) и период с января 2012 по сентябрь 2014 года.

За 3 года первого периода (1994-1996) в детское ЛОР отделение было госпитализировано 146 детей в возрасте от 3 до 14 лет с паратонзиллярным абсцессом и было произведено 195 плановых тонзиллэктомий.

Во второй анализируемый период (2009-2011) количество плановых тонзиллэктомий уменьшилось в 2 раза - до 81, в то время как число больных с паратонзиллярным абсцессом составило 98 человек. Возрастной состав больных с паратонзиллярными абсцессами изменился мало: основную часть в обоих периодах составили дети от 10 до 14 лет (42-49\% ежегодно), однако в последние 
три года наблюдалось 3 ребенка с паратонзиллитами младше 3 лет.

В течение последнего анализируемого периода количество плановых тонзиллэктомий несколько возросло (118), что повлекло за собой уменьшение числа больных с паратонзиллитами (66 случаев).

Наши данные четко демонстрируют основную тенденцию в развитии подхода к выбору тактики лечения хронического тонзиллита за последние 15 лет: число плановых тонзилэктомий у детей сократилось в 1.8 раз, что отражает общую тенденцию щадящего, органосберегающего подхода. Однако рост числа паратонзиллярных абсцессов при снижении хирургической активности свидетельствует о том, что щадящее отношение к небным миндалинам не всегда оправдано [6]. Не исключено, что изменение тактики лечения ХТ является одной из причин повышения частоты гнойных осложнений хронического тонзиллита: паратонзиллярного абсцесса, некротического фасциита и миозита, синдрома токсического шока, первичного перитонита, сепсиса $[7,8]$. Для сокращения числа тонзиллогенных осложнений необходимо проведение диспансеризации детского населения, качественное консервативное лечение хронического тонзиллита и своевременная хирургическая санация больных с декомпенсированным течением заболевания. 


\section{Литература:}

1. Бойко Н.В., Гукасян Е.Л., Быкова В.В. Статистика хирургических вмешательств при хроническом тонзиллите. Вестник оториноларингологии 2008; 5: 234.

2. Бойко Н.В., Бачурина А.С. Аденотомия и аденотонзиллотомия у детей с затруднением носового дыхания. Рос. ринология 2015; 23 (1): 9-12.

3. Gates G.A., Folbre T.W. Indications for adenotonsillectomy //Arch. Otolaryngol. Head Neck Surg. 1986; 112: 501-502.

4. Parker, D.L. Walner N.P. Trends in the indications for pediatric tonsillectomy or adenotonsillectomy // International Journal of Pediatric Otorhinolaryngology 2011; 75: 282-285.

5. Owings M.F., Kozak L.J. Ambulatory and in patient procedure sin the UnitedStates, National Center for Health Statistics. (1996) Available at: http://www.cdc.gov/ nchs/data/series/sr_13/sr13_139.pdf (accessed October 10, 2010).

6. Бойко Н.В., Локшина Л.С., Сорока Г.Г., Бриж Ю.В., Сулина Н.Ю. Изменение подходов к лечению хронического тонзиллита в детском возрасте по материалам Ростовской ЛОР клиники. Вестник оторинолар. 2012; 5: 226.

7. Власова Т.М., Бойко Н.В. Рост числа постстрептококковых осложнений у больных хроническим тонзиллитом. Рос. оторинолар. 2015; S1: 45-47.

8. Galioto N.J. Peritonsillar abscess //American Family Physician 2008; 77 (2): 199-203. 